\title{
Theoretical analysis of cooperation of a turbocharger with a sequentially turbocharged engine
}

\begin{abstract}
The paper presents fundamentals characterising the operation of turbochargers and the dependencies essential for the calculation (the use of balance equations of a turbocharger this purpose) of the total efficiency of a compressor set with respect to the power balance of the respective devices of a turbine. For the assumed conditions of the engine operation - an optimum power distribution has been carried out on the basis of a theoretical analysis as far as the total efficiency is concerned in the compressor set and in the turbine set of a supercharging device. The required pressure drops in the turbine, essential to ensure the power in the compressor have been carried out with respect to the efficiency of each device.
\end{abstract}

Key words: sequential turbocharging, total efficiency of a supercharging device, optimum power distribution of turbochargers

\section{Teoretyczna analiza współpracy turbosprężarkowego urządzenia doładowującego z silnikiem z doladowaniem zakresowym}

\begin{abstract}
W artykule przedstawiono zasadnicze wielkości charakteryzujace prace turbosprężarek oraz zależności niezbędne do obliczenia całkowitej sprawności zespołu sprężarkowego przy uwzględnieniu równowagi mocy z odpowiednimi urządzeniami zespolu turbinowego, wykorzystując do tego celu równania bilansowe turbosprężarki. Następnie, dla założonych warunków pracy silnika, na drodze analizy teoretycznej, dokonano optymalnego pod względem sprawności catkowitej podziału mocy w zespołach sprężarkowych oraz turbinowych urządzenia doładowującego. Określono wymagane spadki ciśnienia po stronie turbin konieczne do zapewnienia mocy potrzebnej po stronie sprężarek przy uwzględnieniu sprawności każdego urządzenia.
\end{abstract}

Słowa kluczowe: doładowanie zakresowe, całkowita sprawność układu doładowującego, podział mocy turbosprężarek

\section{Introduction}

The most efficient way to increase the maximum value of the mean effective pressure is engine supercharging. The greatest possibilities within this scope are created by the application of turbocharging, the advantages of which with a simultaneous reduction of the disadvantages - show a particular usefulness of such a type of supercharging in the future engine designs developed along with the downsizing concepts. This led to a situation where a turbocharger has become one of the most important units of a modern engine. The requirements imposed on turbochargers increase along with the growth in the power of engines and ensuring high values of supercharging pressure required at high supercharging stages in the rated operating conditions is of fundamental significance as well as ensuring adequate supercharging efficiency at part loads. At the same time it is desired to keep the required efficiency of a supercharging device, its promptness in the response to sudden changes in the engine operating conditions as well as its reliability.

Certain possibilities to meet these contradictory requirements are created by the application of variable geometry turbochargers (VTG) that have established their position as a solution predominant in Diesel engines designed for passenger and heavy duty vehicles. At the same time the limits of a single-stage supercharging have become apparent, where the whole characteristic of a compressor is used, covering with its range the areas where the compression efficiency is

\section{Wstęp}

Najskuteczniejszym sposobem zwiększenia maksymalnej wartości średniego ciśnienia użytecznego jest doładowanie silnika. Największe możliwości w tym zakresie stwarza zastosowanie doładowania turbosprężarkowego, którego zalety, przy jednoczesnym ograniczeniu niekorzystnych cech, wskazują na szczególne znaczenie tego typu doładowania w przyszłych konstrukcjach silników opracowywanych zgodnie z koncepcjami downsizingu. Spowodowało to, że turbosprężarka stała się jednym z najważniejszych zespołów współczesnego silnika. Ze wzrostem mocy silników zwiększają się wymagania stawiane turbosprężarkom, przy czym zasadnicze znaczenie ma zapewnienie wysokich wartości ciśnienia doładowania, wymaganych przy dużych stopniach doładowania $\mathrm{w}$ znamionowych warunkach pracy oraz odpowiedniej wydajności doładowania przy obciążeniach częściowych. Jednocześnie pożądane jest zachowanie wymaganej sprawności urządzenia doładowującego, szybkości jego reakcji na gwałtowne zmiany warunków pracy silnika oraz niezawodności.

Pewne możliwości spełnienia tych sprzecznych wymagań stwarza zastosowanie turbosprężarek o zmiennym kącie nachylenia łopatek kierownicy turbiny VTG, które utrwaliły swoją pozycję, jako rozwiązanie dominujące $\mathrm{w}$ silnikach o ZS przeznaczonych do samochodów osobowych i dostawczych. Jednocześnie uwidoczniły się granice doładowania jednostopniowego, w którym z konieczności 
very low. The points of the engine operation can significantly stray from the line of its maximum efficiency. Also the course of the compressor surge line at low intensities of the air flow reduces the possibilities to obtain the required values of the supercharging pressure in the range of lower engine speed. This problem intensifies along with the increase in the rated power and with the extension of the range of the usable engine speed.

The application of sequential turbocharging can be a solution to these problems where two turbochargers are used, most often of different size, connected in a parallel configuration with the possibility of disconnecting one of them. Supercharging of such a type has been known and used since the mid 80 's of the $20^{\text {th }}$ century; however a significant increase in the interest in its further development possibilities has taken place in recent years $[7,10,13]$. It has been demonstrated by the supercharging systems used recently in the mass-produced cars with Diesel engines made by BMW and Opel, very similar in design and described with the term of "Twin-Turbo". In these systems, two turbochargers of different size have been used but - as opposed to the sequential turbocharging - operating in series at certain range of engine speeds $[12,14]$.

Such systems provide the possibility of obtaining both high power concentration in the rated conditions and clear improvement of the course of the maximum torque in the characteristics of full power at low and medium engine speeds. This can be achieved at the same time keeping the fuel consumption on a good level in the conditions of part loads. The advantages of such supercharging show a significant potential for further improvement of the properties of turbocharged vehicle engines, and they determine the appropriateness of carrying out research into their application not only in the passenger but also utility vehicles engines.

\section{Problem description}

A significant inconvenience of such a system reported in the literature $[2,4,5,611,15]$ and confirmed with the results of own observations [8] are the disturbances in the engine operation taking place during the switching of the turbochargers. When a turbocharger of the second sequence is engaged, the compression drops below the values obtained with the first turbocharger in operation. The result of that is the discontinuity of the characteristics of the engine supercharging typical of stepwise (rough) switching of the turbochargers. This is a disadvantageous phenomenon as it leads to a sudden drop in the torque in the characteristic of the engine supercharging and is the reason for a drop in other engine operating parameters.

It results from the tests presented in $[4,5]$ that in such systems with a rough turbocharger switch, the conditions for obtaining the most advantageous course of the engine characteristics is to use turbochargers of different size. Rough switching of the second, smaller turbocharger allows a reduction of the supercharging discontinuity in the characteristics and a reduction of drop in the engine torque, and the switching process can be effected at a significantly higher engine speed. However, with the increased size of a turbocharger used in the lower range of the engine speed, significantly lower super- wykorzystywana jest cała charakterystyka sprężarki, obejmująca również obszary, gdzie sprawność sprężania jest bardzo mała. Punkty pracy silnika mogą znacznie odbiegać od linii jej maksymalnej sprawności. Również przebieg granicy pompowania sprężarki ogranicza możliwości uzyskania wymaganych wartości ciśnienia doładowania przy niewielkich natężeniach przepływu powietrza w zakresie mniejszej prędkości obrotowej silnika. Problem ten nasila się wraz ze wzrostem mocy znamionowej oraz rozszerzeniem zakresu użytecznej prędkości obrotowej silnika.

Rozwiązaniem tych problemów może być zastosowanie doładowania zakresowego, w którym wykorzystywane są zazwyczaj dwie turbosprężarki, najczęściej różnej wielkości, połączone równolegle $\mathrm{z}$ możliwością odłączania jednej z nich. Doładowanie tego typu jest znane i stosowane już od połowy lat 80 . XX wieku, jednak w ostatnich latach nastąpił wyraźny wzrost zainteresowania jego możliwościami rozwojowymi $[7,10,13]$. Wskazują na to zastosowane ostatnio w seryjnie wytwarzanych samochodach osobowych z silnikami o ZS firm BMW i Opel układy doładowania, bardzo zbliżone konstrukcyjnie i określane terminem „Twin-Turbo”. W układach tych również wykorzystane zostały dwie turbosprężarki różnej wielkości, lecz w przeciwieństwie do doładowania zakresowego pracujące w pewnym zakresie prędkości obrotowych silnika również w układzie szeregowym [12, 14].

Układy tego typu dają możliwości uzyskiwania zarówno dużej koncentracji mocy w warunkach znamionowych, jak i wyraźnej poprawy przebiegu krzywej maksymalnego momentu obrotowego na charakterystyce pełnej mocy, przy małych i średnich wartościach prędkości obrotowej silnika. Można to uzyskać przy jednoczesnym zachowaniu korzystnych wartości zużycia paliwa w warunkach obciążeń częściowych. Zalety takiego doładowania wskazują na znaczny potencjał dalszej poprawy właściwości turbodoładowanych silników samochodowych oraz określają celowość prowadzenia badań w kierunku ich zastosowania nie tylko w silnikach samochodów osobowych, lecz również pojazdów użytkowych.

\section{Opis problemu}

Istotną niedogodnością takiego układu, sygnalizowaną w literaturze [2, 4, 5, 6 11, 15] oraz potwierdzoną wynikami własnych obserwacji [8], są zaburzenia w pracy silnika występujące podczas przełączania turbosprężarek. Kiedy włączana jest turbosprężarka drugiego zakresu, spręż spada poniżej wartości uzyskiwanej przy pracującej pierwszej turbosprężarce. Rezultatem tego jest typowa dla skokowego przełączania turbosprężarek nieciągłość charakterystyki doładowania silnika. Jest to zjawisko niekorzystne, gdyż prowadzi do gwałtownego spadku momentu obrotowego na charakterystyce silnika i jest przyczyną pogorszenia pozostałych wskaźników pracy.

Z badań przedstawionych w $[4,5]$ wynika, że w układach tego typu, ze skokowym włączaniem kolejnych turbosprężarek, warunkiem uzyskania najkorzystniejszego przebiegu charakterystyk silnika jest zastosowanie turbosprężarek różnej wielkości. Skokowe włączanie do pracy drugiej, mniejszej turbosprężarki pozwala zredukować nieciągłość 
charging pressures are obtained in the power characteristics than in a system with turbochargers of identical size. Such a situation indicates specific problems with the selection of turbochargers that will be a compromise between the possibility of ensuring an advantageous course of the torque and the required engine acceleration in the range of operation of one turbocharger and the value of the torque drop and deterioration of other operating parameters during the switch of the second turbocharger. This turns one's attention to the necessity of a precise diagnosis of the properties of systems of such type in order to identify factors conditioning the formation of such a discontinuity and the possibilities of preventing it.

A gradual engagement of the second turbocharger used e.g. in the Audi engine can be a solution that eliminates the discontinuity of the characteristics of the engine with a sequential turbocharging [2]. However, regardless of the method of engaging of the second sequence turbocharger, adequate power distribution between both the compressor set and the turbine set will play a significant role $[1,3]$. This becomes of particular significance for systems with stepwise engaging of the turbochargers. In such systems certain possibilities of reduction of the discontinuity of the engine torque while engaging the second turbocharger can be sought in such a matching of the turbochargers to the engine and ensuring such conditions of cooperation between them that is possible to achieve the highest total efficiency of the supercharging system. The total efficiency of the system consisting of two turbochargers is determined by selected values of the total efficiency of the compressor set and the turbine set. Maintaining high efficiency of the compressor set can be partly compensated by instantaneous changes in the supercharging pressure, thus keeping the required air excess coefficient without the necessity to significantly reduce a fuel charge. In turn, obtaining high values of the turbine set supports the reduction of the exhaust gases outlet choking that - with simultaneous reduction of the demand for power by the compressor set - allows keeping the favourable conditions of the charge exchange. This creates potential possibilities of significant reduction of both the torque drop and rise in the specific fuel consumption.

When matching the turbochargers to an engine with a sequential turbocharging, the necessity to keep adequate distribution of power of the compressor set and the turbine set is important not only because of the total efficiency of the system but also because of the design and properties of the compressors. Particular attention should be drawn to the surge line of the compressors. In the characteristics of the largest compressor of the first sequence, the surge line is flatter than in the characteristics of the smaller compressor of the second sequence. This may cause significant risk of reaching the surge line when - at the increasing load - its power share is too small. This may also cause problems ensuring good values of fuel consumption during operation at part loads. Because of that it is purposeful to strive for a possibly large share of power of the larger compressor of the first sequence, whereas while engaging the smaller compressor of the second sequence, the course of the surge line charakterystyki doładowania oraz spadek momentu obrotowego silnika, a proces przełączania może być realizowany przy znacznie większej prędkości obrotowej. Jednak przy zwiększonych rozmiarach turbosprężarki wykorzystywanej w dolnym zakresie prędkości obrotowej, na charakterystyce pełnej mocy osiągane są znacznie mniejsze ciśnienia doładowania niż w układzie z turbosprężarkami jednakowej wielkości. Sytuacja taka wskazuje na problemy z doborem turbosprężarek, który będzie kompromisem pomiędzy możliwością zapewnienia korzystnego przebiegu momentu obrotowego oraz wymaganych przyspieszeń silnika w zakresie pracy jednej turbosprężarki a wielkością spadku momentu obrotowego oraz pogorszenia pozostałych wskaźników operacyjnych podczas włączania drugiej turbosprężarki. Zwraca to uwagę na konieczność dokładnego rozpoznania właściwości układów tego typu w celu identyfikacji czynników warunkujących powstawanie tej nieciągłości oraz możliwości jej przeciwdziałania.

Rozwiązaniem eliminującym nieciągłość charakterystyki silnika z doładowaniem zakresowym może być stopniowe włączanie drugiej turbosprężarki, wykorzystane m.in. w silniku firmy Audi [2]. Jednak niezależnie od sposobu włączania turbosprężarki drugiego zakresu, zasadniczą rolę odgrywać będzie odpowiedni podział mocy między oba urządzenia zespołu sprężarkowego oraz turbinowego $[1,3]$. Nabiera to szczególnego znaczenia dla układów ze skokowym włączaniem kolejnych turbosprężarek. W układach tego typu pewne możliwości zmniejszenia nieciągłości momentu obrotowego silnika podczas włączania drugiej turbosprężarki upatrywać można w takim dopasowaniu turbosprężarek do silnika oraz zapewnieniu warunków współpracy między nimi, przy których możliwe będzie osiągnięcie jak największej całkowitej sprawności układu doładowującego. Łączną sprawność układu złożonego z dwóch turbosprężarek określają wyodrębnione wartości sprawności całkowitej zespołu sprężarkowego oraz zespołu turbinowego. Zachowanie dużej sprawności zespołu sprężarkowego może częściowo kompensować chwilowe zmiany ciśnienia doładowania, sprzyjając utrzymaniu wymaganego nadmiaru powietrza bez konieczności istotnej redukcji dawki paliwa. Z kolei uzyskiwanie dużych wartości sprawności zespołu turbinowego sprzyja zmniejszeniu dławienia wylotu spalin, co przy jednoczesnym ograniczeniu zapotrzebowania na moc przez zespół sprężarkowy pozwala na zachowanie korzystnych warunków wymiany ładunku. Stwarza to możliwości istotnego ograniczenia zarówno spadku momentu obrotowego, jak i wzrostu jednostkowego zużycia paliwa.

Podczas doboru turbosprężarek do silnika z doładowaniem zakresowym konieczność zachowania odpowiedniego podziału mocy zespołu sprężarkowego oraz turbinowego jest ważna nie tylko z uwagi na całkowitą sprawność układu, ale również ze względu na budowę i właściwości turbosprężarek. Szczególną uwagę należy zwrócić na granicę pompowania sprężarek. Na charakterystyce większej sprężarki pierwszego zakresu granica pompowania przebiega bardziej płasko niż na charakterystyce mniejszej sprężarki drugiego zakresu. Może to powodować znaczne niebezpieczeństwo osiągnięcia 
will be defined - at a determined value of the supercharging pressure created by the operating larger turbocharger - by its minimum required air expenditure that also must comply with the area of a stable compressor operation.

The possibility of application of many combinations of inlet boxes for turbines and rotors of compressors within the range of one turbocharger type dimension is an essential facilitation in the procedure of selection of turbochargers. Such procedure ensures achieving the required match of turbochargers to the engine in the majority of cases.

The balance equations of a turbocharger are the basis for the analysis of the efficiency of the sequential turbocharging system. A diagram of such system has been presented in the Fig. 1, where respective denotations of pressures and temperatures characterising the conditions of the turbochargers' operation have been plotted.

For the assumed conditions of the engine operation, one is to consider a possibility to obtain the highest total efficiency of the turbocharging unit consisting of two turbochargers connected in parallel, with two different flow characteristics. This is connected with the necessity to determine the optimum power distribution of the compressor set and the turbine set as far as the efficiency is concerned. By making use of the balance equations and the fundamental rates characterising the turbochargers' operation one is to carry out calculations of the total efficiency of the compressor set taking into account the power balance with respective devices of the turbine set. This will allow to determine the fundamental parameters of the turbine set required to ensure the power needed on the compressors' side taking into account the efficiency and the stability of operation of each device.

The following conditions of cooperation with the engine apply in the turbocharger:

- the power balance of the $\mathrm{N}_{\mathrm{t}}$ turbine and the $\mathrm{N}_{\mathrm{s}}$ compressor:

$$
\mathrm{N}_{\mathrm{s}}=\mathrm{N}_{\mathrm{t}}
$$

- the speeds of the rotors of the compressor $n s$ and the turbine $n_{t}$ are identical and equal to the speed of the turbocharger shaft $n_{w}$ :

$$
\mathrm{n}_{\mathrm{s}}=\mathrm{n}_{\mathrm{t}}=\mathrm{n}_{\mathrm{w}}
$$

- the mass balance of the charge flowing through the engine and the turbocharger. The expenditure of exhaust gases flowing through the $G_{t}$ turbine is equal to the expenditure of the air flowing through the $\mathrm{G}_{\mathrm{s}}$ compressor and the $\mathrm{G}_{\mathrm{e}}$ fuel consumption less the loss of charge through the $G_{n}^{e}$ leaks: granicy pompowania, gdy przy wzrastającym obciążeniu jej udział mocy będzie zbyt mały. Może to również stwarzać problemy z zapewnieniem korzystnych wartości zużycia paliwa podczas pracy przy obciążeniach częściowych. $Z$ tych powodów celowe jest dążenie do możliwie dużego udziału mocy większej sprężarki pierwszego zakresu. Natomiast podczas włączania mniejszej sprężarki drugiego zakresu przebieg granicy pompowania określać będzie (przy ustalonej wartości ciśnienia doładowania wytwarzanej przez pracującą większą turbosprężarkę) jej minimalny, wymagany wydatek powietrza, który również musi odpowiadać obszarowi statecznej pracy sprężarki.

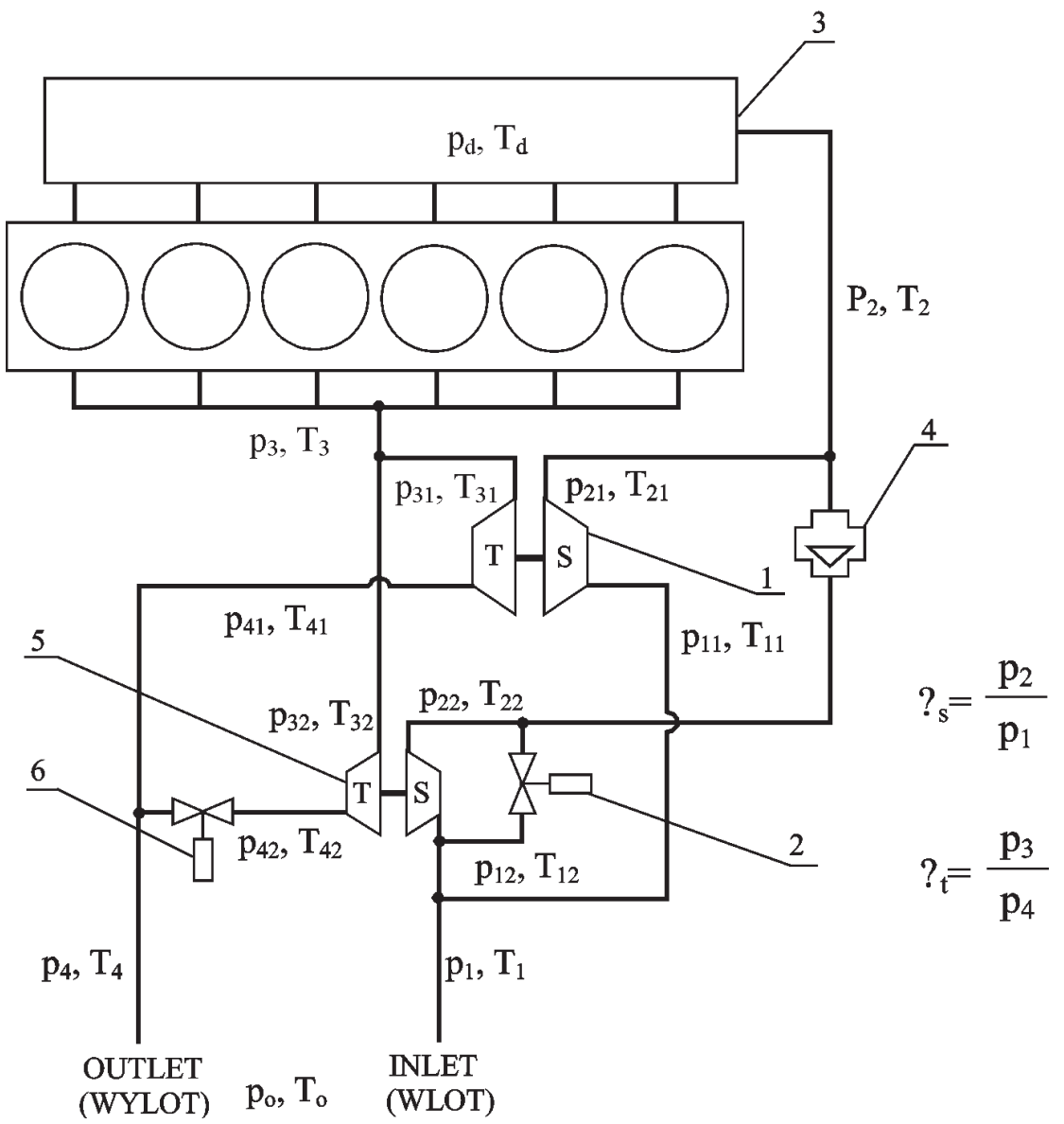

Fig. 1. Diagram of the analysis of efficiency of a sequential turbo-charging system: 1 - first sequence turbocharger, 2 - air release valve, 3 - air equalising tank, 4 - compressor disengaging valve, 5 - second sequence turbocharger, 6 - turbine disengaging valve

Rys. 1. Schemat do analizy sprawności układu doładowania zakresowego: 1 - turbosprężarka pierwszego zakresu, 2 - zawór upustowy powietrza, 3-zbiornik wyrównawczy powietrza, 4 zawór właczający sprężarkę, 5-turbosprężarka drugiego zakresu, 6-zawór włączajacy turbinę

Istotnym ułatwieniem w doborze turbosprężarek jest możliwość stosowania wielu kombinacji skrzyń wlotowych turbin i wirników sprężarek w zakresie jednego typorozmiaru turbosprężarki. Takie postępowanie w większości przypadków zapewnia uzyskanie wymaganego dopasowania turbosprężarek do silnika.

Podstawą analizy sprawności układu doładowania zakresowego są równania bilansowe turbosprężarki. Schemat ta- 


$$
\mathrm{G}_{\mathrm{t}}=\mathrm{G}_{\mathrm{s}}+\mathrm{G}_{\mathrm{e}}-\mathrm{G}_{\mathrm{n}}
$$

The work of adiabatic compression of $1 \mathrm{~kg}$ of air in the compressor $\mathrm{H}_{\mathrm{s}}^{\mathrm{ad}}$ at the compressor ratio $\pi_{\mathrm{s}}=\mathrm{p}_{2} / \mathrm{p}_{1}$ and with the exponent of the adiabate $\kappa$ is:

$$
\mathrm{H}_{\mathrm{s}}^{\mathrm{ad}}=\frac{\kappa}{\kappa-1} \cdot \mathrm{T}_{1} \cdot \mathrm{R} \cdot\left(\left(\frac{\mathrm{p}_{2}}{\mathrm{p}_{1}}\right)^{\frac{\kappa-1}{\kappa}}-1\right)
$$

The actual work $\mathrm{H}_{\mathrm{s}}$ of the compression is defined by the $\eta_{s}$ efficiency of the compressor:

$$
\mathrm{H}_{\mathrm{s}}=\frac{\mathrm{H}_{\mathrm{s}}^{\mathrm{ad}}}{\eta_{\mathrm{s}}}
$$

The power necessary to drive the compressor with the $\eta_{s}$ efficiency and at the $\mathrm{G}_{\mathrm{s}}$ expenditure is:

$$
\mathrm{N}_{\mathrm{s}}=\mathrm{G}_{\mathrm{s}} \cdot \mathrm{H}_{\mathrm{s}}^{\mathrm{ad}} / \eta_{\mathrm{s}}
$$

For the given value of the combustion air factor $\lambda$, the expenditure of exhaust gases flowing through the turbine can be derived from the dependence:

$$
\mathrm{G}_{\mathrm{t}}=\mathrm{G}_{\mathrm{s}} \cdot \frac{1+\lambda \cdot \mathrm{L}_{\mathrm{t}}}{\lambda \cdot \mathrm{L}_{\mathrm{t}}}
$$

The work of the adiabatic expansion of $1 \mathrm{~kg}$ of exhaust gases in the turbine $\mathrm{H}_{\mathrm{t}}^{\mathrm{ad}}$ at the expansion ratio $\pi_{\mathrm{t}}=\mathrm{p}_{3} / \mathrm{p}_{4}$ and with the exponent of the adiabate $\kappa_{t}$ is:

$$
\mathrm{H}_{\mathrm{t}}^{\mathrm{ad}}=\frac{\kappa_{\mathrm{t}}}{\kappa_{\mathrm{t}}-1} \mathrm{R}_{\mathrm{t}} \cdot \mathrm{T}_{3} \cdot\left[1-\left(\frac{\mathrm{p}_{4}}{\mathrm{p}_{3}}\right)^{\frac{\kappa_{\mathrm{t}}-1}{\kappa_{\mathrm{t}}}}\right]
$$

The power of the turbine with the efficiency $\eta_{e}$ is determined by the dependence:

$$
\mathrm{N}_{\mathrm{t}}=\mathrm{G}_{\mathrm{t}} \cdot \mathrm{H}_{\mathrm{t}}^{\mathrm{ad}} \cdot \eta_{\mathrm{t}}
$$

The total efficiency $\eta_{\mathrm{ts}}$ of a turbocharger can be determined from the power balance equation (1):

$$
\eta_{\mathrm{ts}}=\eta_{\mathrm{s}} \cdot \eta_{\mathrm{t}}=\frac{\mathrm{H}_{\mathrm{s}}^{\mathrm{ad}}}{\mathrm{H}_{\mathrm{t}}^{\mathrm{ad}}} \cdot \frac{\lambda \cdot \mathrm{L}_{\mathrm{t}}}{1+\lambda \cdot \mathrm{L}_{\mathrm{t}}}
$$

\section{Assessment of power share of turbochargers operating in parallel}

\subsection{Efficiency of a compressor set}

With a parallel connection of compressors in the system without air bleeding adjustment, the air expenditure flowing through the $\mathrm{G}_{\mathrm{p}}$ engine corresponds to the total air expenditure of the $\mathrm{G}_{\mathrm{s} . \mathrm{c}}$ compressor set that is equal to the sum of expenditures of the compressors of the first sequence $G_{1 \mathrm{~s}}$ and the second sequence $\mathrm{G}_{\mathrm{s} 2}$ :

$$
\mathrm{G}_{\mathrm{p}}=\mathrm{G}_{\mathrm{s} . \mathrm{c}}=\mathrm{G}_{\mathrm{s} 1}+\mathrm{G}_{\mathrm{s} 2}
$$

By introducing a share coefficient of the expenditure of the first sequence compressor $\mathrm{W}_{\mathrm{p}}$ : kiego układu przedstawiono na rys. 1, na którym naniesiono stosowne oznaczenia ciśnień i temperatur charakteryzujące warunki pracy turbosprężarek.

Dla założonych warunków pracy silnika należy rozważyć możliwość uzyskania jak największej sprawności całkowitej zespołu doładowującego złożonego z dwóch połączonych równolegle turbosprężarek o odmiennych charakterystykach przepływowych. Wiąże się to z koniecznością wyznaczenia optymalnego pod względem sprawności podziału mocy urządzeń zespołu sprężarkowego oraz turbinowego. Wykorzystując równania bilansowe oraz zasadnicze wielkości charakteryzujące pracę turbosprężarek, należy dokonać obliczeń całkowitej sprawności zespołu sprężarkowego, biorąc pod uwagę równowagę mocy z odpowiednimi urządzeniami zespołu turbinowego. Umożliwi to wyznaczenie zasadniczych wielkości zespołu turbinowego wymaganych do zapewnienia mocy potrzebnej po stronie sprężarek, przy jednoczesnym uwzględnieniu sprawności oraz stabilności pracy każdego urządzenia.

W turbosprężarce obowiązują następujące warunki współpracy z silnikiem:

- bilans mocy turbiny $\mathrm{N}_{\mathrm{t}}$ oraz sprężarki $\mathrm{N}_{\mathrm{s}}$ (1)

- prędkości obrotowe wirników sprężarki $n_{\mathrm{s}}$ oraz turbiny $\mathrm{n}_{\mathrm{t}} \mathrm{są}$ jednakowe i równe prędkości wału turbosprężarki $\mathrm{n}_{\mathrm{w}}(2)$

- bilans masy ładunku przepływającego praz silnik oraz turbosprężarkę. Wydatek spalin przepływających przez turbinę $\mathrm{G}_{\mathrm{t}}$ równy jest sumie wydatku powietrza przepływającego przez sprężarkę $\mathrm{G}_{\mathrm{s}}$ oraz zużycia paliwa $\mathrm{G}_{\mathrm{e}}$, pomniejszonej o straty ładunku przez nieszczelności $\mathrm{G}_{\mathrm{n}}$ (3).

Praca adiabatycznego sprężania $1 \mathrm{~kg}$ powietrza w sprężarce $\mathrm{H}_{\mathrm{s}}^{\mathrm{ad}}$ przy sprężu $\pi_{\mathrm{s}}=\mathrm{p}_{2} / \mathrm{p}_{1}$ oraz wykładniku adiabaty к wynosi (4).

Rzeczywista praca sprężania określona jest sprawnością sprężarki $\eta_{\mathrm{s}}(5)$.

Moc potrzebna do napędu sprężarki o sprawności $\eta_{\mathrm{s}}$ oraz przy wydatku $\mathrm{G}_{\mathrm{s}}$ wynosi (6).

Dla zadanej wartości współczynnika nadmiaru powietrza $\lambda$ wydatek spalin przepływających przez turbinę może być określony z zależności (7).

Praca adiabatycznego rozprężania w turbinie $1 \mathrm{~kg}$ spalin przy stopniu rozprężania $H_{t}^{\text {ad }}$ i wykładniku adiabaty $\kappa_{t}$ wynosi (8).

Moc turbiny o sprawności $\eta_{t}$ określa zależność (9).

$\mathrm{Z}$ równania bilansu mocy (1) wyznaczyć można całkowitą sprawność turbosprężarki $\eta_{\mathrm{ts}}(10)$.

\section{Ocena podziału mocy turbosprężarek pracujących równolegle}

\subsection{Sprawność zespołu sprężarkowego}

Przy równoległym połączeniu sprężarek, w układzie bez regulacji upustowej powietrza, wydatek powietrza przepływającego przez silnik $G_{p}$ odpowiada całkowitemu wydatkowi zespołu sprężarkowego $G_{s . c}$, który równy jest sumie wydatków sprężarki pierwszego $\mathrm{G}_{1 \mathrm{~s}}$ oraz drugiego zakresu $\mathrm{G}_{\mathrm{s} 2}(11)$. 


$$
\mathrm{W}_{\mathrm{p}}=\frac{\mathrm{G}_{\mathrm{s} 1}}{\mathrm{G}_{\mathrm{s} . \mathrm{c}}}=\frac{\mathrm{G}_{\mathrm{s} 1}}{\mathrm{G}_{\mathrm{s} 2}+\mathrm{G}_{\mathrm{s} 1}}
$$

the quantity of air flowing through each compressor will be:

$$
\begin{gathered}
\mathrm{G}_{\mathrm{s} 1}=\mathrm{G}_{\mathrm{s} . \mathrm{c}} \cdot \mathrm{W}_{\mathrm{p}} \\
\mathrm{G}_{\mathrm{s} 2}=\mathrm{G}_{\mathrm{s} . \mathrm{c}} \cdot\left(1-\mathrm{W}_{\mathrm{p}}\right)
\end{gathered}
$$

If one assumes identical conditions of the air flow in the inlet pipes of each compressor, regardless of the air expenditure, then the compression will take place at the same values of compression, from the pressure of $p_{11}=p_{12}=p_{1}$ and the temperature of $\mathrm{T}_{11}=\mathrm{T}_{12}=\mathrm{T}_{1}$ up to the pressure of $\mathrm{p}_{11}=\mathrm{p}_{21}=\mathrm{p}_{2}$ (Fig. 1). However, if the heat exchange is neglected, the air temperature $\mathrm{T}_{2}$ compressed by the compressor set can be determined from the energy balance:

$$
\mathrm{T}_{2} \cdot \mathrm{G}_{\mathrm{s} . \mathrm{c}}=\mathrm{G}_{\mathrm{s} 1} \cdot \mathrm{T}_{21}+\mathrm{G}_{\mathrm{s} 2} \cdot \mathrm{T}_{22}
$$

The temperature $T_{2}$ will be dependent on the efficiency and the share of expenditure of each compressor.

The balance of energy delivered and carried away by the compressor set consisting of two compressors connected in parallel can be presented in the form of:

$$
\mathrm{c}_{\mathrm{p}} \cdot \mathrm{G}_{\mathrm{s} . \mathrm{c}} \cdot \mathrm{T}_{1}=\mathrm{N}_{\mathrm{s} . \mathrm{c}}+\mathrm{c}_{\mathrm{p}} \cdot \mathrm{G}_{\mathrm{s} . \mathrm{c}} \cdot \mathrm{T}_{2}
$$

For identical conditions of the air flow through each compressor $\left(\mathrm{H}_{\mathrm{s} 1}^{\mathrm{ad}}=\mathrm{H}_{\mathrm{s} 2}^{\mathrm{ad}}=\mathrm{H}_{\mathrm{s}}^{\mathrm{ad}}\right)$, the expression defining the total power of the compressor set $\mathrm{N}_{\text {s.c }}$ can be presented in the form of:

$$
\mathrm{G}_{\mathrm{s} . \mathrm{c}} \frac{\mathrm{H}_{\mathrm{s}}^{\mathrm{ad}}}{\eta_{\mathrm{s} . \mathrm{c}}}=\mathrm{G}_{\mathrm{s} 1} \cdot \frac{\mathrm{H}_{\mathrm{s}}^{\mathrm{ad}}}{\eta_{\mathrm{s} 1}}+\mathrm{G}_{\mathrm{s} 2} \frac{\mathrm{H}_{\mathrm{s}}^{\mathrm{ad}}}{\eta_{\mathrm{s} 2}}
$$

The power balance equation (17) together with the dependencies of (13) and (14) form a basis for the determination of the total efficiency of the compressor set. Considering the differences in the expenditure $\mathrm{G}_{\mathrm{s} 1}, \mathrm{G}_{\mathrm{s} 2}$ and the efficiency $\eta_{\mathrm{s} 1}$, $\eta_{\mathrm{s} 2}$ of each compressor, the total efficiency of the compressor set $\eta_{\text {s.c }}$ derived from the dependence (16) will be:

$$
\eta_{\mathrm{s.c}}=\frac{\eta_{\mathrm{s} 1} \cdot \eta_{\mathrm{s} 2}}{\mathrm{~W}_{\mathrm{p}} \cdot\left(\eta_{\mathrm{s} 2}-\eta_{\mathrm{s} 1}\right)+\eta_{\mathrm{s} 1}}
$$

The Fig. 2 presents changes in the total efficiency of the compressor set calculated according to the dependence (18) at different shares of the $\mathrm{W}_{\mathrm{p}}$ expenditure of the first sequence compressor. The optimum efficiency depends both on the share of expenditure and on the graph of efficiency of each compressor.

\subsection{Efficiency of a turbine set}

With a parallel connection of turbines in the system without the exhaust gas bleeding adjustment, the total expenditure of the $\mathrm{G}_{\text {t.c }}$ turbine set is equal to the sum of expenditures of the turbines of the first sequence $G_{t 1}$ and the second sequence $\mathrm{G}_{\mathrm{t} 2}$ :

$$
\mathrm{G}_{\mathrm{t} . \mathrm{c}}=\mathrm{G}_{\mathrm{t} 1}+\mathrm{G}_{\mathrm{t} 2}
$$

By introducing a share coefficient of the expenditure of the first sequence turbine $\mathrm{W}_{\mathrm{t}}$ :
Wprowadzając współczynnik udziału wydatku sprężarki pierwszego zakresu $\mathrm{W}_{\mathrm{p}}$ równe (12),

ilość powietrza przepływającego przez każdą sprężarkę wyniesie (13) i (14).

Jeżeli założy się jednakowe warunki przepływu powietrza w przewodach dolotowych każdej sprężarki, niezależne od wydatku powietrza, to sprężanie przebiegać będzie przy takich samych wartościach sprężu, od ciśnienia $\mathrm{p}_{11}=\mathrm{p}_{12}=\mathrm{p}_{1}$ $\mathrm{i}$ temperatury $\mathrm{T}_{11}=\mathrm{T}_{12}=\mathrm{T}_{1}$ do ciśnienia $\mathrm{p}_{21}=\mathrm{p}_{22}=\mathrm{p}_{2}$ (rys. 1). Natomiast, jeśli pominie się wymianę ciepła, temperaturę powietrza $T_{2}$ sprężonego przez zespół sprężarkowy można wyznaczyć z bilansu energii - równanie (15).

Temperatura $\mathrm{T}_{2}$ zależeć będzie od sprawności oraz udziału wydatku każdej sprężarki.

Bilans energii doprowadzonej oraz odprowadzonej przez zespół sprężarkowy złożony z dwóch równolegle połączonych sprężarek można przedstawić w postaci (16).

Dla jednakowych warunków przepływu powietrza przez każdą sprężarkę $\left(\mathrm{H}_{\mathrm{s} 1}^{\mathrm{ad}}=\mathrm{H}_{\mathrm{s} 2}^{\mathrm{ad}}=\mathrm{H}_{\mathrm{s}}^{\mathrm{ad}}\right)$, wyrażenie określające całkowitą moc zespołu sprężarkowego $\mathrm{N}_{\mathrm{s} . \mathrm{c}}$ można przedstawić w postaci (17).

Równanie bilansu mocy (17) wraz z zależnościami (13), (14) stanowią podstawę do wyznaczenia całkowitej sprawności zespołu sprężarkowego. Uwzględniając różnice w wydatku $\mathrm{G}_{\mathrm{s} 1}, \mathrm{G}_{\mathrm{s} 2}$ oraz sprawności $\eta_{\mathrm{s} 1}, \eta_{\mathrm{s} 2}$ każdej ze sprężarek, całkowita sprawność zespołu sprężarkowego $\eta_{\text {s.c }}$ wyznaczona z zależności (16) wyniesie (18).

Na rysunku 2 przedstawiono zmiany sprawności całkowitej zespołu sprężarkowego obliczone według zależności (18) przy różnych udziałach wydatku $\mathrm{W}_{\mathrm{p}}$ sprężarki pierwszego zakresu. Optimum sprawności całkowitej zależy zarówno od udziału wydatku, jak i od przebiegu sprawności każdej sprężarki.

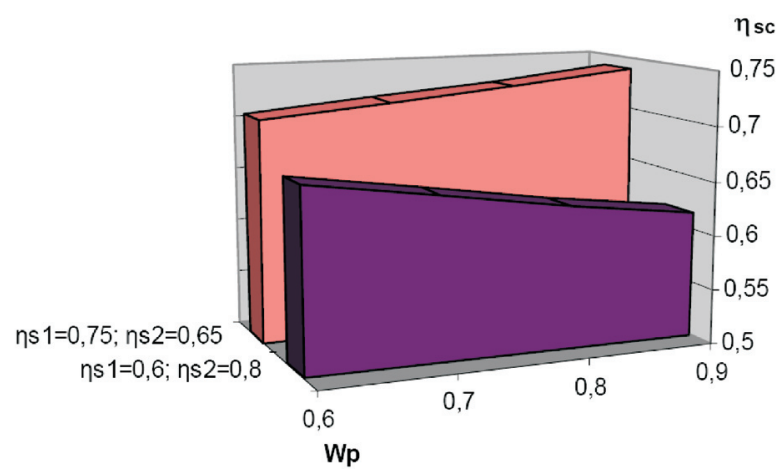

Fig. 2. Calculated values of the total efficiency of the compressor set $\eta_{\text {s.c }}$ depending on the share coefficient $\mathrm{W}_{\mathrm{p}}$ at different values of efficiency of the first sequence compressor $\eta_{\mathrm{s} 1}$ and the second sequence compressor $\eta_{\mathrm{s} 2}$ Rys. 2. Obliczone wartości sprawności całkowitej zespotu sprężarkowego $\eta_{s . c} w$ zależności od wspótczynnika udziału $W_{p}$, przy różnych wartościach sprawności $\eta_{s l}$ sprężarki pierwszego oraz $\eta_{s 2}$ drugiego zakresu

\subsection{Sprawność zespołu turbinowego}

Przy równoległym połączeniu turbin, w układzie bez regulacji upustowej spalin, całkowity wydatek zespołu turbinowego $\mathrm{G}_{\mathrm{t} . \mathrm{c}}$ równy jest sumie wydatków turbiny pierwszego $\mathrm{G}_{\mathrm{t} 1}$ oraz drugiego zakresu $\mathrm{G}_{\mathrm{t} 2}$ - równanie (19). 


$$
\mathrm{W}_{\mathrm{t}}=\frac{\mathrm{G}_{\mathrm{t} 1}}{\mathrm{G}_{\mathrm{t} . \mathrm{c}}}
$$

the quantity of exhaust gases flowing through each turbine will be:

$$
\begin{gathered}
\mathrm{G}_{\mathrm{t} 1}=\mathrm{G}_{\mathrm{t} . \mathrm{c}} \cdot \mathrm{W}_{\mathrm{t}} \\
\mathrm{G}_{\mathrm{t} 2}=\mathrm{G}_{\mathrm{t} . \mathrm{c}} \cdot\left(1-\mathrm{W}_{\mathrm{t}}\right)
\end{gathered}
$$

If one assumes identical conditions of supply of turbines and if one assumes that the pressure losses over the stretch of an outlet pipe behind each turbine are equal (regardless of the exhaust gases expenditure), then the expansion of the exhaust gases in the turbines will take place at an identical expansion ratio, starting from the pressure of $\mathrm{p}_{31}=\mathrm{p}_{32}=\mathrm{p}_{3}$ and the temperature of $T_{31}=T_{32}=T_{3}$ up to the pressure of $\mathrm{p}_{41}=\mathrm{p}_{42}=\mathrm{p}_{4}$ (Fig. 1). However, if the heat exchange is neglected, the final temperature $\mathrm{T}_{4}$ of the exhaust gases flowing out to the atmosphere will result from the energy balance:

$$
\mathrm{T}_{4} \cdot \mathrm{G}_{\mathrm{t} . \mathrm{c}}=\mathrm{G}_{\mathrm{t} 1} \cdot \mathrm{T}_{41}+\mathrm{G}_{\mathrm{t} 2} \cdot \mathrm{T}_{42}
$$

The temperature $\mathrm{T}_{4}$ will be dependant on the efficiency and the share of expenditure of each turbine.

The balance of energy delivered and carried away by the turbine set can be presented in the form of:

$$
c_{p} \cdot G_{t . c} \cdot T_{3}=N_{t . c}+c_{p} \cdot G_{t . c} \cdot T_{4}
$$

The power of the turbine set $\mathrm{N}_{\mathrm{t.c}}$ at identical conditions of the exhaust gases flow through each turbine $\mathrm{H}_{\mathrm{t} 1}^{\mathrm{ad}}=\mathrm{H}_{\mathrm{t} 2}^{\mathrm{ad}}=\mathrm{H}_{\mathrm{t}}^{\mathrm{ad}}$ is determined by the expression:

$$
\mathrm{G}_{\mathrm{t} . \mathrm{c}} \cdot \mathrm{H}_{\mathrm{t}}^{\mathrm{ad}} \cdot \eta_{\mathrm{t} . \mathrm{c}}=\mathrm{G}_{\mathrm{t} 1} \cdot \mathrm{H}_{\mathrm{t}}^{\mathrm{ad}} \cdot \eta_{\mathrm{t} 1}+\mathrm{G}_{\mathrm{t} 2} \cdot \mathrm{H}_{\mathrm{t}}^{\mathrm{ad}} \cdot \eta_{\mathrm{t} 2}
$$

The expression (25) together with equations (21) and (22) form a basis for the determination of the total efficiency of the turbine set. Considering the differences in the expenditure $G_{t 1}, G_{t 2}$ and the efficiency $\eta_{t 1}, \eta_{t 2}$ of each turbine, the total efficiency of the turbine set $\eta_{t . c}$ derived from the dependence (25) will be:

$$
\eta_{\mathrm{t} . \mathrm{c}}=\mathrm{W}_{\mathrm{t}} \cdot \eta_{\mathrm{t} 1}+\left(1-\mathrm{W}_{\mathrm{t}}\right) \cdot \eta_{\mathrm{t} 2}
$$

The Fig. 3 presents the changes in the total efficiency of the turbine set determined according to the dependence (26).

\subsection{Balance equations for the supercharging system}

However, for the assessment of the total efficiency of the supercharging system consisting of two different turbochargers connected in parallel, the determination of the compressor set efficiency from the expression (18), and the turbine set from the dependence (26) is far from being sufficient. While having an analytical description of the characteristics of each turbine, one can only calculate from the dependence (26) the course of the efficiency of the turbine set for a particular expansion ratio $\pi_{t}$, depending on the share of the expenditure of the exhaust gases of the turbine set. This will allow a determination of an optimum distribution (as far as the efficiency is concerned) of the turbines' flow capacity but without taking the cooperation with the compressor into account. One can easily prove that such optimum will be departing from the optimum distribution of power
Wprowadzając współczynnik udziału wydatku turbiny pierwszego zakresu $\mathrm{W}_{\mathrm{t}}$ równy (20), ilość spalin przepływających przez każdą turbinę wyniesie (21) i (22).

Przy założeniu jednakowych warunków zasilania turbin oraz przyjęciu, że straty ciśnienia na odcinku przewodu wylotowego za każdą turbiną są równe (niezależne od wydatku spalin), rozprężanie spalin w turbinach przebiegać będzie przy jednakowym stopniu rozprężania od ciśnienia $\mathrm{p}_{31}=\mathrm{p}_{32}=\mathrm{p}_{3}$ oraz temperatury $\mathrm{T}_{31}=\mathrm{T}_{32}=\mathrm{T}_{3}$ do ciśnienia $\mathrm{p}_{41}=\mathrm{p}_{42}=\mathrm{p}_{4}$ (rys. 1). Natomiast, jeśli pominie się wymianę ciepła, końcowa temperatura spalin $\mathrm{T}_{4}$ wypływających do otoczenia wynikać będzie z bilansu energii (23). Temperatura $\mathrm{T}_{4}$ zależeć będzie od sprawności oraz udziału wydatku każdej turbiny.

Bilans energii doprowadzonej oraz odprowadzonej przez zespół turbinowy można przedstawić w postaci (24).

Moc zespołu turbinowego $\mathrm{N}_{\mathrm{t.c}}$ przy jednakowych warunkach przepływu spalin przez każdą turbinę $\left(\mathrm{H}_{\mathrm{t} 1}^{\mathrm{ad}}=\mathrm{H}_{\mathrm{t} 2}^{\mathrm{ad}}=\mathrm{H}_{\mathrm{t}}^{\mathrm{ad}}\right)$ określa wyrażenie (25).

Wyrażenie (25) wraz z równaniami (21), (22) stanowią podstawę wyznaczenia całkowitej sprawności zespołu turbinowego. Po uwzględnieniu różnic w wydatku $G_{t 1}, G_{t 2}$ oraz sprawności $\eta_{\mathrm{t} 1}, \eta_{\mathrm{t} 2}$ każdej z turbin, całkowita sprawność zespołu turbinowego $\eta_{\text {t.c }}$ wyznaczona z zależności (25) wyniesie (26).

Zmiany sprawności całkowitej zespołu turbinowego wyznaczone według zależności (26) przedstawiono na rys. 3.

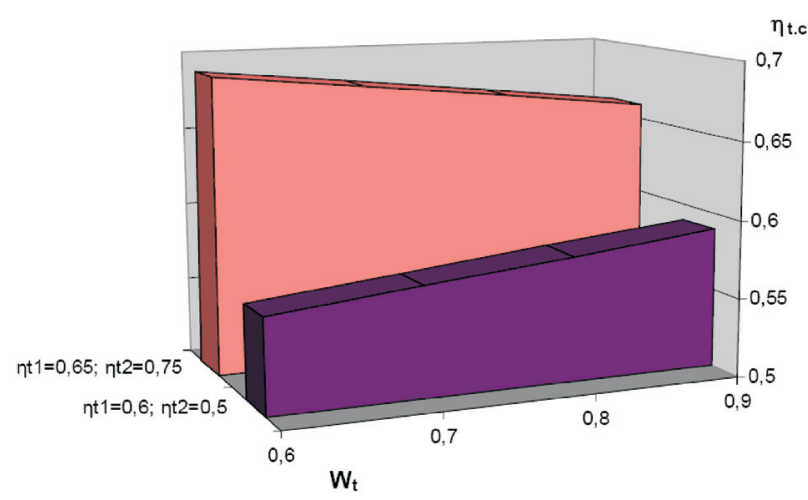

Fig. 3. Calculated values of the total efficiency of the turbine set $\eta_{\text {t.c }}$ depending on the share coefficient $\mathrm{W}$, for different values of efficiency of the first sequence turbine $\eta_{\mathrm{t} 1}$ and the second sequence turbine $\eta_{\mathrm{t} 2}$

Rys. 3. Obliczone wartości sprawności całkowitej zespolu turbinowego

$\eta_{t . c} w$ zależności od współczynnika udziału $W_{t}$ dla różnych wartości sprawności turbiny $\eta_{t 1}$ pierwszego oraz $\eta_{t 2}$ drugiego zakresu

\subsection{Równania bilansowe układu doładowującego}

Do oceny całkowitej sprawności zespołu doładowującego złożonego z dwóch różnych turbosprężarek połączonych równolegle, wyznaczenie sprawności zespołu sprężarkowego z wyrażenia (18) oraz zespołu turbinowego z zależności (26) jest niewystarczające. Dysponując analitycznym opisem charakterystyki każdej turbiny, z zależności (26) można jedynie obliczyć przebieg sprawności zespołu turbinowego dla określonego stopnia rozprężania $\pi_{t}$, w zależności od udziału wydatku spalin każdej turbiny. Umożliwia to wyznaczenie optymalnego, ze względu na sprawność, podziału 
of the compressor set. A similar situation will take place in case of an attempt to determine an optimum efficiency of a compressor set.

In order to achieve the power needed on the compressors' side, taking into account the adequate efficiency, a particular energy of the exhaust gases before the turbine set is essential, i.e. the distribution of power of each turbine cannot be selected freely. For a specified supercharging pressure, the power distribution and the exhaust gases pressure before the turbine unit must be considered in connection with the total efficiency of the supercharging system and the distribution of power of the compressor set. At distribution of power of the supercharging unit, one is also to take into account the limitations of the supercharging pressure resulting from the course of the surge line of the compressors. Moreover, the power balance for each turbocharger must be met.

In the case of a parallel connection of turbochargers, the equations of the power balance dependencies apply:

- for the first sequence turbocharger:

$$
\mathrm{W}_{\mathrm{t}} \cdot \mathrm{G}_{\mathrm{t} . \mathrm{c}} \cdot \mathrm{H}_{\mathrm{t} 1}^{\mathrm{ad}} \cdot \eta_{\mathrm{t} 1}=\mathrm{W}_{\mathrm{p}} \cdot \mathrm{G}_{\mathrm{s} . \mathrm{c}} \cdot \frac{\mathrm{H}_{\mathrm{s} 1}^{\mathrm{ad}}}{\eta_{\mathrm{s} 1}}
$$

- for the second sequence turbocharger:

$$
\left(1-W_{t}\right) \cdot G_{t . c} \cdot H_{t 2}^{\mathrm{ad}} \cdot \eta_{\mathrm{t} 2}=\left(1-\mathrm{W}_{\mathrm{p}}\right) \cdot \mathrm{G}_{\mathrm{s} . \mathrm{c}} \cdot \frac{\mathrm{H}_{\mathrm{s} 2}^{\mathrm{ad}}}{\eta_{\mathrm{s} 2}}
$$

At the same time, the power balance must also be met for the compressor set and for the turbine set:

$$
\mathrm{N}_{\mathrm{s} 1}+\mathrm{N}_{\mathrm{s} 2}=\mathrm{N}_{\mathrm{t} 1}+\mathrm{N}_{\mathrm{t} 2}
$$

The mass balance for the system is:

$$
\mathrm{G}_{\mathrm{t} . \mathrm{c}}=\mathrm{G}_{\mathrm{t} 1}+\mathrm{G}_{\mathrm{t} 2}=\mathrm{G}_{\mathrm{s} . \mathrm{c}} \cdot \frac{1+\lambda \cdot \mathrm{L}_{\mathrm{t}}}{\lambda \cdot \mathrm{L}_{\mathrm{t}}}
$$

By taking into account the dependencies (27), (29), the total efficiency of the first sequence compressor will be:

$$
\begin{aligned}
\eta_{\mathrm{ts} 1}= & \eta_{\mathrm{s} 1} \cdot \eta_{\mathrm{t} 1}=\frac{\mathrm{W}_{\mathrm{p}}}{\mathrm{W}_{\mathrm{t}}} \cdot \frac{\lambda \cdot \mathrm{L}_{\mathrm{t}}}{1+\lambda \cdot \mathrm{L}_{\mathrm{t}}} \cdot \frac{\mathrm{R} \cdot \mathrm{T}_{11}}{\mathrm{R}_{\mathrm{t}} \cdot \mathrm{T}_{31}} \cdot \\
& \frac{\kappa \cdot\left(\kappa_{\mathrm{t}}-1\right)}{(\kappa-1) \cdot \kappa_{\mathrm{t}}} \cdot \frac{\left(\frac{\mathrm{p}_{21}}{\mathrm{p}_{11}}\right)^{\frac{\kappa-1}{\kappa}}-1}{1-\left(\frac{\mathrm{p}_{41}}{\mathrm{p}_{31}}\right)^{\frac{\kappa_{\mathrm{t}}-1}{\kappa_{\mathrm{t}}}}}
\end{aligned}
$$

By grouping the constant values:

$$
\eta_{\mathrm{ts} 1}=\eta_{\mathrm{s} 1} \cdot \eta_{\mathrm{t} 1}=A \cdot \frac{W_{\mathrm{p}}}{W_{\mathrm{t}}} \cdot \frac{\mathrm{T}_{11}}{\mathrm{~T}_{31}} \cdot \frac{\left(\frac{\mathrm{p}_{21}}{\mathrm{p}_{11}}\right)^{\frac{\kappa-1}{\kappa}}-1}{1-\left(\frac{p_{41}}{p_{31}}\right)^{\frac{\kappa_{\mathrm{t}}-1}{\kappa_{\mathrm{t}}}}}
$$

Whereas the efficiency of the second sequence turbocharger will be: przepustowości turbin, ale bez uwzględnienia współpracy z zespołem sprężarkowym. Można udowodnić, że optimum to będzie odbiegać od optymalnego podziału mocy zespołu sprężarkowego. Podobna sytuacja będzie miała miejsce przy poszukiwaniu optymalnej sprawności zespołu sprężarkowego.

Do osiągnięcia mocy potrzebnej po stronie sprężarek, przy uwzględnianiu odpowiedniej sprawności, niezbędna jest określona energia spalin przed zespołem turbinowym, a więc podział mocy każdej turbiny nie może być dowolnie wybrany. Dla określonego ciśnienia doładowania podział mocy oraz ciśnienie spalin przed zespołem turbinowym muszą być rozpatrywane w powiązaniu z całkowitą sprawnością układu doładowującego i podziałem mocy zespołu sprężarkowego. Przy podziale mocy zespołu sprężarkowego należy brać pod uwagę ograniczenia wynikające z przebiegu granicy pompowania sprężarek. Musi być również spełniony bilans mocy dla każdej turbosprężarki.

W ogólnym przypadku równoległego połączenia turbosprężarek obowiązują równania bilansu mocy:

- dla turbosprężarki pierwszego zakresu (27)

- dla turbosprężarki drugiego zakresu (28).

Jednocześnie bilans mocy musi być również spełniony dla zespołu sprężarkowego oraz zespołu turbinowego równanie (29).

Bilans masy dla układu wynosi (30).

Po uwzględnieniu zależności (27), (29) całkowita sprawność turbosprężarki pierwszego zakresu wyniesie (31).

Grupując stałe wielkości, otrzyma się (32).

Natomiast sprawność turbosprężarki drugiego zakresu wynosi (33).

Po odpowiednich przekształceniach obowiązuje równanie (34) dla stopnia rozprężania turbiny pierwszego zakresu w zależności od wymaganego sprężu, sprawności oraz podziału wydatków sprężarek i turbin, a dla turbiny drugiego zakresu równanie (35).

Zgodnie z przyjętymi założeniami dotyczącymi jednakowych warunków przepływu powietrza i spalin przez każdą turbosprężarkę w zależnościach (34), (35) należy przyjąć: $\mathrm{p}_{21}=\mathrm{p}_{22}=\mathrm{p}_{2}, \mathrm{p}_{11}=\mathrm{p}_{12}=\mathrm{p}_{1}, \mathrm{p}_{41}=\mathrm{p}_{42}=\mathrm{p}_{4}$ oraz $\mathrm{p}_{31}=\mathrm{p}_{32}=\mathrm{p}_{3}$. Rozwiązując układ równań (30), (34), (35), można, przy założonych wartościach ciśnienia $\mathrm{p}_{2}$ oraz znanych charakterystykach sprawności turbosprężarek, ustalić związek pomiędzy $\mathrm{W}_{\mathrm{t}}$ oraz $\mathrm{W}_{\mathrm{p}}$, dla których spełniony będzie bilans mocy i masy urządzenia doładowującego. Stanowi to podstawę wyznaczenia wymaganych przekrojów skrzyń wlotowych turbin.

\section{Obliczenia charakterystycznych wielkości układu doładowującego $\mathrm{w}$ doładowaniu zakresowym}

Wykorzystując przedstawione wcześniej zależności oraz równania bilansowe, przeprowadzono przykładowe obliczenia wielkości charakterystycznych układu doładowującego. Przyjęto, że w celu zachowania wymaganego współczynnika nadmiaru powietrza $\lambda=1,5$ konieczne jest zapewnienie zużycia powietrza przez silnik $\mathrm{G}_{\mathrm{p}}=0,2 \mathrm{~kg} / \mathrm{s}$ przy ciśnieniu 


$$
\eta_{\mathrm{ts} 2}=\eta_{\mathrm{s} 2} \cdot \eta_{\mathrm{t} 2}=\mathrm{A} \cdot \frac{\left(1-\mathrm{W}_{\mathrm{p}}\right)}{\left(1-\mathrm{W}_{\mathrm{t}}\right)} \cdot \frac{\mathrm{T}_{12}}{\mathrm{~T}_{32}} \cdot \frac{\left(\frac{\mathrm{p}_{22}}{\mathrm{p}_{12}}\right)^{\frac{\mathrm{\kappa}-1}{\kappa}}-1}{1-\left(\frac{\mathrm{p}_{42}}{\mathrm{p}_{32}}\right)^{\frac{\mathrm{k}_{\mathrm{t}}-1}{\mathrm{k}_{\mathrm{t}}}}}
$$

After appropriate transformations, the equation for the expansion ratio of the first sequence turbine shall apply, depending on the required compression, efficiency and distribution of expenditures of compressors and turbines:

$$
\frac{\mathrm{p}_{31}}{\mathrm{p}_{41}}=\left(1-\mathrm{A} \cdot\left[\left(\frac{\mathrm{p}_{21}}{\mathrm{p}_{11}}\right)^{\frac{\kappa-1}{\kappa}}-1\right] \cdot \frac{\mathrm{W}_{\mathrm{p}}}{\mathrm{W}_{\mathrm{t}}} \cdot \frac{\mathrm{T}_{11}}{\mathrm{~T}_{31}} \cdot \frac{1}{\eta_{\mathrm{ts} 1}}\right)^{\frac{1-\kappa_{\mathrm{t}}}{\kappa_{\mathrm{t}}}}
$$

and for the second sequence turbine:

$$
\begin{aligned}
& \frac{p_{32}}{p_{42}}=\left(1-A \cdot\left[\left(\frac{p_{22}}{p_{12}}\right)^{\frac{\kappa-1}{\kappa}}-1\right] .\right. \\
& \left.\cdot \frac{\left(1-W_{p}\right)}{\left(1-W_{t}\right)} \cdot \frac{T_{12}}{T_{32}} \cdot \frac{1}{\eta_{\text {ts2 }}}\right)^{\frac{1-\kappa_{t}}{\kappa_{t}}}
\end{aligned}
$$

According to the adopted assumptions concerning the identical conditions of the air and the exhaust gases flows through each turbocharger, the following are to be taken in the dependencies of (34), (35): $\mathrm{p}_{21}=\mathrm{p}_{22}=\mathrm{p}_{2}, \mathrm{p}_{11}=\mathrm{p}_{12}=\mathrm{p}_{1}$, $\mathrm{p}_{41}=\mathrm{p}_{42}=\mathrm{p}_{4}$ and $\mathrm{p}_{31}=\mathrm{p}_{32}=\mathrm{p}_{3}$. By solving the system of equations of (30), (34), (35) through a trial method, one can (for the assumed values of pressure $\mathrm{p}_{2}$ and with known characteristics of efficiency of turbochargers) determine a relation between $\mathrm{W}_{\mathrm{t}}$ and $\mathrm{W}_{\mathrm{p}}$, for which the balance of power and mass of a supercharging device will be met. This allows a determination of the required sections of the inlet boxes of turbines.

\section{Calculations of the characteristic parameters of the supercharging system in sequential tur- bo-charging}

By making use of the previously presented dependencies and the balance equations, we have carried out demonstration calculations of characteristic values of the supercharging system. It has been assumed that - in order to keep the required air excess coefficient of $\lambda=1.5-$ it is necessary to ensure the air consumption by the engine of $\mathrm{G}_{\mathrm{p}}=0.2 \mathrm{~kg} / \mathrm{s}$ at the supercharging pressure of $\mathrm{p}_{2}=0.15 \mathrm{MPa}$. A constant temperature of exhaust gases of $\mathrm{T}_{31}=\mathrm{T}_{32}=\mathrm{T}_{3}$ has been assumed, equal to $950 \mathrm{~K}$ and the turbine supplied at constant pressure. In order to simplify the calculations also constant values of efficiency of compressors and turbines have been taken: $\eta_{\mathrm{s} 1}=0.8$ and $\eta_{\mathrm{t} 1}=0.7$ for the first sequence turbocharger and $\eta_{\mathrm{s} 2}=0.7 \mathrm{i} \eta_{\mathrm{t} 2}=0.6$ for the second sequence turbocharger.

For the assessment of the power of the turbochargers in sequential turbocharging, values of selected parameters of a turbocharging system have been determined, depending on the share coefficient of the first sequence turbocharger's doładowania $\mathrm{p}_{2}=0,15 \mathrm{MPa}$. Założono stałą temperaturę spalin $\mathrm{T}_{31}=\mathrm{T}_{32}=\mathrm{T}_{3}$ równą $950 \mathrm{~K}$ oraz stałociśnieniowe zasilanie turbiny. Dla uproszczenia obliczeń przyjęto również stałe wartości sprawności sprężarek i turbin $\eta_{\mathrm{s} 1}=0,8$ i $\eta_{\mathrm{t} 1}=0,7$ dla turbosprężarki pierwszego zakresu oraz $\eta_{\mathrm{s} 2}=0,7 \mathrm{i} \eta_{\mathrm{t} 2}=0,6$ dla turbosprężarki drugiego zakresu.

Do oceny podziału mocy turbosprężarek w doładowaniu zakresowym określono wartości wybranych parametrów turbosprężarkowego układu doładowującego w zależności od współczynnika udziału wydatku sprężarki pierwszego zakresu $\mathrm{W}_{\mathrm{p}}$. Stanowi to podstawę wyboru najkorzystniejszego ze względu na sprawność układu doładowującego podziału wydatków turbosprężarek, przy jednoczesnym uwzględnieniu warunków ich współpracy z silnikiem. W świetle tego kryterium szczególnego znaczenia nabierają wymagane wartości współczynnika udziału wydatku turbiny pierwszego zakresu $\mathrm{W}_{\mathrm{t}}$ oraz ciśnienie spalin $\mathrm{p}_{\mathrm{t}}$.

$\mathrm{Na}$ rysunku 4 przedstawiono wyniki obliczeń dla zadanych wartości sprawności turbosprężarek. Wzrost udziału wydatku sprężarki pierwszego zakresu $\mathrm{W}_{\mathrm{p}}$, któremu odpowiada ściśle określona wartość $W_{t}$, prowadzi do wzrostu całkowitej sprawności układu doładowującego $\eta_{\text {ts.c }}$. W rezultacie zmniejszeniu ulega ciśnienie spalin pt przed zespołem turbinowym, które jest konieczne dla zachowania wymaganego ciśnienia doładowania i przepływu powietrza do silnika. Wzrost ciśnienia doładowania w stosunku do ciśnienia spalin $\mathrm{p}_{2} / \mathrm{p}_{3}$ sprzyja zmniejszeniu pracy wymiany ładunku oraz zwiększeniu sprawności ogólnej silnika. Sytuacja taka wskazuje na celowość zachowania możliwie dużego udziału sprężarki pierwszego zakresu, co jest również korzystne ze względu na przebieg charakterystyki momentu obrotowego podczas przełączania turbosprężarek.

Jednak przy ocenie podziału wydatków turbosprężarek konieczne jest również uwzględnienie warunku statecznej pracy sprężarek, a szczególnie sprężarki drugiego zakresu. Przy założonym stałym ciśnieniu doładowania zmniejszanie wydatku sprężarki drugiego zakresu jest ograniczone z jednej strony przebiegiem granicy pompowania zastosowanej sprężarki, z drugiej zaś zakresem użytecznej prędkości obrotowej silnika, który określać będzie wymagany, maksymalny jej wydatek. Na rysunku 5 przedstawiono przykładowe charakterystyki wydatków sprężarki WSK B-3C dla pierwszego zakresu oraz sprężarki WSK B-65 - drugiego zakresu. Na charakterystyki naniesione zostały punkty pracy silnika, wyznaczone dla różnych wartości współczynnika $W_{p}$. $\mathrm{Z}$ położenia punktów pracy na charakterystyce sprężarki WSK B-65 wynika, że dla założonych warunków obliczeniowych jej stabilna współpraca z silnikiem możliwa jest przy wydatku odpowiadającym wartości współczynnika $\mathrm{W}_{\mathrm{p}}$ poniżej 0,8 . Zapewnia to wystarczającą odległość do granicy pompowania oraz nie ogranicza zakresu użytecznych prędkości obrotowych silnika.

Wybór wartości współczynnika $\mathrm{W}_{\mathrm{p}}$, której odpowiada ściśle określona wartość $W_{t}$ (rys. 4) umożliwia wstępne określenie wymaganego przekroju skrzyń wlotowych AT zespołu turbinowego. Przy uproszczeniu przepływu spalin przez zespół turbinowy do zasilania stałociśnieniowego 
expenditure of $\mathrm{W}_{\mathrm{p}}$. This forms a basis for the selection of the most advantageous distribution of expenditures of turbochargers as far as the efficiency of the supercharging system is concerned, simultaneously taking into account the conditions of their cooperation with the engine. In light of this criterion, the required values of the share coefficient of the expenditure of the first sequence turbine $\mathrm{W}_{t}$ and the pressure of exhaust gases $p_{t}$ become of particular significance.

Fig. 4 presents the results of the calculations for the set values of efficiency of turbochargers. The increase in the expenditure of the first sequence compressor $\mathrm{W}_{\mathrm{p}}$ - that is matched by a precisely specified value of $\mathrm{W}_{\mathrm{t}}$, - leads to the increase in the total efficiency of the supercharging system $\eta_{\text {ts.c }}$. As a result, the pressure $p_{t}$ of exhaust gases before the turbine set (required in order to keep the supercharging pressure and the air flow to the engine) gets reduced. The increase in the supercharging pressure in relation to the exhaust gases pressure $\mathrm{p}_{2} / \mathrm{p}_{3}$ supports a reduction of the charge exchange work and the increase in the total efficiency of the engine. Such a situation indicates the purposefulness of keeping the highest possible share of the first sequence compressor, which is also advantageous due to the course of the torque characteristics during the switching of the turbochargers.

However, while assessing the distribution of the turbochargers' expenditures it is also necessary to take into account the condition of a stable operation of compressors, and the second sequence compressor in particular. At the assumed constant supercharging pressure, the reduction of the second sequence compressor's expenditure is limited by the course of the surge line of the used compressor on one side, and - on the other side - by the range of usable engine speed that will be determining its required maximum expenditure. Fig. 5 presents example characteristics of the WSK B-3C compressor's expenditures for the first sequence, and the WSK B-65 for the second sequence. For different values of the Wp coefficient, points of the engine operation have been plotted on the characteristics. It results from the location of the operating points in the characteristic of the WSK B-65 compressor that, for the assumed computational conditions, enable its stable cooperation with the engine at the expenditure corresponding to the value of the $\mathrm{Wp}$ coefficient below 0.8 . It ensures sufficient distance to the surge line and it does not restrict the range of usable engine speeds.

The selection of value of the $\mathrm{W}_{\mathrm{p}}$ coefficient - that is matched by a precisely specified value of $\mathrm{W}_{t}$ (Fig. 4) - enables preliminary determination of the required section of inlet boxes $\mathrm{A}_{\mathrm{T}}$ of the turbine set. With a simplification of the exhaust gases flow through the turbine set, for the constant pressure supply the following equation applies:

$$
\mathrm{G}_{\mathrm{s}}=\frac{\lambda \cdot \mathrm{L}_{\mathrm{t}}}{1+\lambda \cdot \mathrm{L}_{\mathrm{t}}} \cdot \mathrm{A}_{\mathrm{T}} \cdot \psi_{\mathrm{T}} \cdot \rho_{\mathrm{t}} \cdot \sqrt{2 \cdot \mathrm{R}_{\mathrm{t}} \cdot \mathrm{T}_{3}}
$$

Hence, the section area of the inlet box of the first sequence turbine is:

$$
\mathrm{A}_{\mathrm{T} 1}=\frac{\mathrm{G}_{\mathrm{s} . \mathrm{c}} \cdot \frac{1+\lambda \cdot \mathrm{L}_{\mathrm{t}}}{\lambda \cdot \mathrm{L}_{\mathrm{t}}} \cdot \mathrm{W}_{\mathrm{t}}}{\psi_{\mathrm{T} 1} \cdot \rho_{\mathrm{t}} \cdot \sqrt{2 \cdot \mathrm{R}_{\mathrm{t}} \cdot \mathrm{T}_{3}}}
$$

obowiązuje równanie (36).

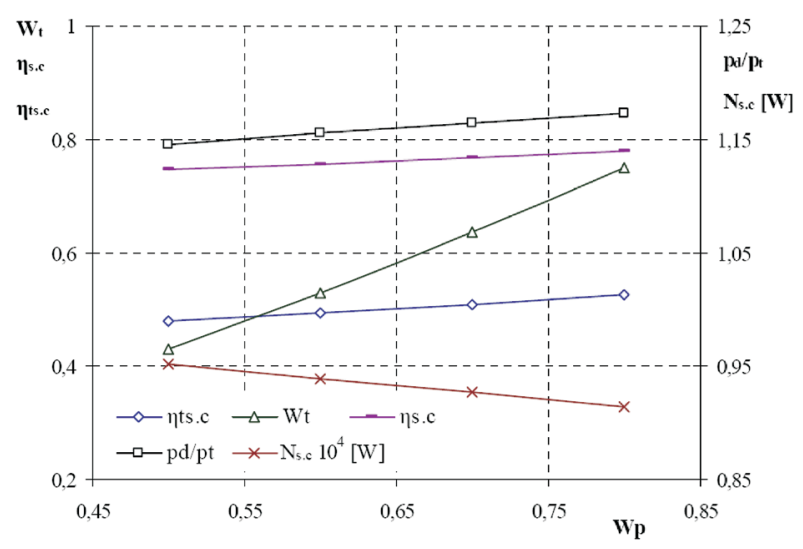

Fig. 4. Characteristic values of a turbo-charging unit for the assessment of the distribution of power of turbochargers in sequential turbo-charging: $\mathrm{W}_{\mathrm{p}}-$ coefficient of share of the first sequence compressor's expenditure, $\eta_{t, c}$ - total efficiency of the supercharging system, $\mathrm{W}_{\mathrm{t}}-$ coefficient of share of the first sequence turbine's expenditure, $p_{2} / p_{3}-$ ratio of supercharging pressure to exhaust gases pressure, $\mathrm{N}_{\mathrm{s.c}}-$ power of the compressor set, $\eta_{\mathrm{scc}}$ - efficiency of compressor set

Rys. 4. Wielkości charakterystyczne turbosprężarkowego zespolu dotadowujacego do oceny podzialu mocy turbosprężarek $w$ doładowaniu zakresowym: $W_{p}-$ wspótczynnik udziatu wydatku sprężarki pierwszego zakresu, $\eta_{\text {tcc }}$ - sprawność catkowita układu doładowujacego, $W_{t}$ - wspótczynnik udziału wydatku turbiny pierwszego zakresu, $p_{2} / p_{3}-$ stosunek ciśnienia doładowania do ciśnienia spalin, $N_{\mathrm{sc}}$ - moc zespolu sprężarkowego, $\eta_{\text {s.c }}$-sprawność zespotu sprężarkowego

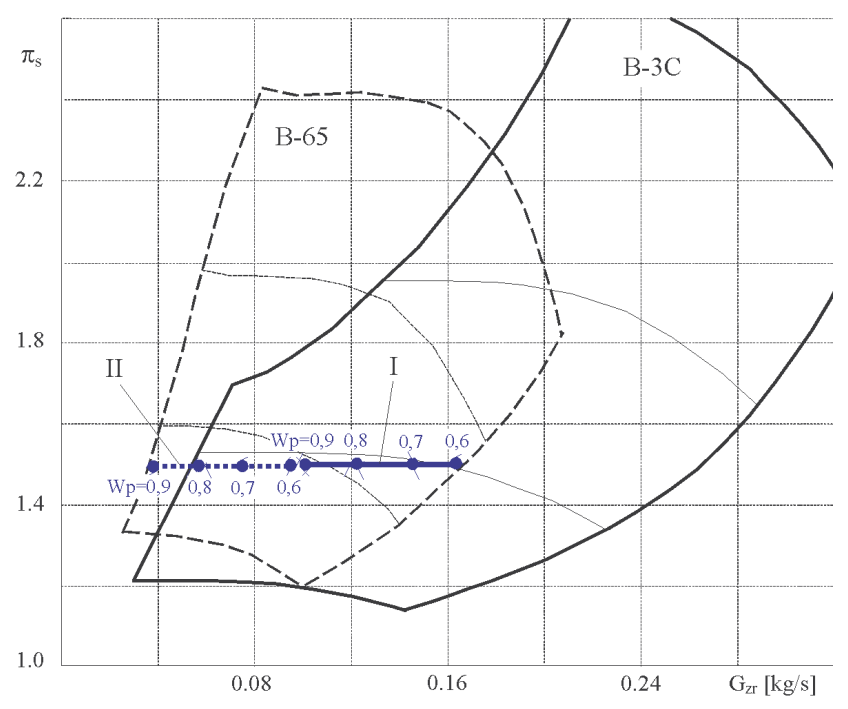

Fig. 5. Characteristics of expenditures of B-3C and B-65 turbochargers with plotted points of the engine operation for different $\mathrm{W}_{\mathrm{p}}$ values at constant supercharging pressure of $\mathrm{p}_{2}=0.15 \mathrm{MPa}$ : I - line of co-operation with the engine for the B-3C first sequence compressor, II - line of co-operation with the engine for the B-65 second sequence compressor

Rys. 5. Charakterystyki wydatków turbosprężarek B-3C oraz B-65 z naniesionymi punktami pracy silnika dla różnych wartości $W_{p}$ przy stałym ciśnieniu doładowania $p_{2}=0,15$ MPa: I-linia wspótpracy z silnikiem dla sprężarki B-3C pierwszego zakresu, II - linia wspótpracy z silnikiem dla sprężarki B-65 drugiego zakresu

Skąd przekrój pola powierzchni skrzyni wlotowej turbiny pierwszego zakresu wynosi (37), a dla turbiny drugiego zakresu (38). 
and for the second sequence turbine:

$$
\mathrm{A}_{\mathrm{T} 2}=\frac{\mathrm{G}_{\mathrm{s} . \mathrm{c}} \cdot \frac{1+\lambda \cdot \mathrm{L}_{\mathrm{t}}}{\lambda \cdot \mathrm{L}_{\mathrm{t}}} \cdot\left(1-\mathrm{W}_{\mathrm{t}}\right)}{\psi_{\mathrm{T} 2} \cdot \rho_{\mathrm{t}} \cdot \sqrt{2 \cdot \mathrm{R}_{\mathrm{t}} \cdot \mathrm{T}_{3}}}
$$

The rate of flow $\psi_{\mathrm{T}}$ through the turbine in the equations of (37) and (38) is calculated from the dependence:

$$
\psi_{\mathrm{T}}=\sqrt{\frac{\kappa_{\mathrm{t}}}{\kappa_{\mathrm{t}}-1} \cdot\left[\left(\frac{p_{3}}{p_{4}}\right)^{\frac{2}{\kappa_{\mathrm{t}}}}-\left(\frac{p_{3}}{p_{4}}\right)^{\frac{\kappa_{\mathrm{t}}+1}{\kappa_{\mathrm{t}}}}\right]}
$$

For the value of $\mathrm{W}_{\mathrm{p}}=0.7$, at which stable operation of compressors is ensured, the calculated sections of inlet boxes for turbines are: $\mathrm{A}_{\mathrm{T} 1}=11 \mathrm{~cm}^{2}$ and $\mathrm{A}_{\mathrm{T} 2}=4.2 \mathrm{~cm}^{2}$.

\section{Summary}

The paper discusses issues related to the selection of adequate construction of a supercharging unit and to ensuring favourable conditions of its cooperation with an engine. The analysis of the characteristic parameters of the sequential turbocharging system consisting of two different turbochargers connected in parallel shows an additional problem that is associated with the necessity to ensure adequate conditions of cooperation between two turbochargers. It is particularly important at the phase of switching of the operation modes between the turbochargers and is of fundamental importance for the continuity of the engine characteristics.

Despite the fact that the calculations have been carried out with many simplifying assumptions, they allow a formulation of general conclusions concerning the required distribution of power of the turbochargers that ensures the most favourable conditions of their cooperation with the engine. The total efficiency of the supercharging system has been determined in particular. The required pressure of the exhaust gases, expenditures and sections of the inlet boxes for each turbine have been calculated, at which the balance equations for the turbochargers are met.

The determining of the required sections of the inlet boxes for the turbines taking into account the conditions of operation of the turbochargers with the engine forms a basis for a selection of the constructional parameters of a supercharging system and the characteristics of the switching system.

The presented dependencies can also be used for the assessment of the matching of the turbochargers to the engine taking into account the actual conditions of their cooperation. However, this requires an application of mathematical models of the engine - a turbocharger set that includes changes in the courses of the characteristics of each turbocharger at pulsatory flow of the exhaust gases that in fact also depend on the engine load and speed. This creates possibilities of use of the optimisation methods at the selection of the constructional parameters of a supercharging system. A description of such a model developed by the author, adapted to the case of sequential turbocharging has been presented in the paper [9].
W równaniach (37) i (38) liczba przepływu przez turbinę $\psi_{\mathrm{T}}$ obliczana jest z zależności (39).

Dla wartości współczynnika $\mathrm{W}_{\mathrm{p}}=0,7$, przy której zapewniona jest stabilna praca sprężarek, obliczone przekroje skrzyń wlotowych turbin wynoszą: $\mathrm{A}_{\mathrm{T} 1}=11 \mathrm{~cm}^{2}$ oraz $\mathrm{A}_{\mathrm{T} 2}=4,2 \mathrm{~cm}^{2}$.

\section{Podsumowanie}

W pracy zwrócono uwagę na problemy związane z wyborem odpowiedniej konstrukcji układu doładowującego i zapewnieniem korzystnych warunków jego współpracy z silnikiem. Analiza wielkości charakterystycznych układu doładowania zakresowego złożonego z dwóch różnych turbosprężarek połączonych równolegle wskazuje na dodatkowy problem, który związany jest z koniecznością zapewnienia również odpowiednich warunków współpracy między dwiema turbosprężarkami. Jest to szczególnie ważne w fazie przełączania trybów pracy pomiędzy turbosprężarkami i ma zasadnicze znaczenie dla zachowania ciągłości charakterystyki silnika.

Pomimo tego, że obliczenia przeprowadzono przy wielu założeniach upraszczających, jednak pozwalają one na formułowanie ogólnych wniosków dotyczących wymaganego podziału mocy turbosprężarek, przy którym zapewnione są najkorzystniejsze warunki ich współpracy z silnikiem. W szczególności wyznaczona została całkowita sprawność układu doładowującego. Obliczono wymagane ciśnienie spalin, wydatki oraz przekroje skrzyń wlotowych każdej turbiny, przy których spełnione są równania bilansowe dla turbosprężarek.

Wyznaczenie wymaganych przekrojów skrzyń wlotowych turbin przy uwzględnieniu warunków współpracy turbosprężarek z silnikiem stanowi podstawę doboru parametrów konstrukcyjnych układu doładowującego oraz charakterystyki układu przełączającego.

Przedstawione zależności mogą być również wykorzystane do oceny dopasowania turbosprężarek do silnika przy uwzględnieniu rzeczywistych warunków ich współpracy. Wymaga to jednak wykorzystania modeli matematycznych układu silnik-turbosprężarka uwzględniających zmiany przebiegu charakterystyk każdej turbosprężarki przy pulsacyjnym przepływie spalin, które istotnie zależą również od prędkości obrotowej i obciążenia silnika. Stwarza to możliwości użycia metod optymalizacyjnych przy doborze parametrów konstrukcyjnych układu doładowującego. Opis takiego modelu opracowanego przez autora, dostosowanego do przypadku doładowania zakresowego, przedstawiony zostały w pracy [9].

Artykut recenzowany 


\section{Abbreviations and nomenclature/Skróty i oznaczenia}

Ge fuel consumption/godzinowe zużycie paliwa

$\mathrm{G}_{\mathrm{n}}$ possible losses of medium through leakage/strata ladunku przez nieszczelności

$\mathrm{G}_{\mathrm{p}}$ quantity of air flowing through the engine/zuzycie powietrza przez silnik

$\mathrm{G}_{\mathrm{s}}$ air expenditure of the compressor/wydatek sprężarki

$\mathrm{G}_{\mathrm{s} . \mathrm{c}}$ total air expenditure of the compressor set/catkowity wydatek zespolu sprężarkowego

$\mathrm{G}_{\mathrm{t}}$ expenditure of the compressor/wydatek turbiny

$\mathrm{G}_{\mathrm{t} . \mathrm{t}}$ total expenditure of the turbine set/calkowity wydatek zespotu turbinowego

$\mathrm{H}_{\mathrm{t}}^{\mathrm{ad}}$ work of adiabatic expansion of exhaust gases in the turbine/ praca adiabatycznego rozprężania $w$ turbinie

$\mathrm{H}_{\mathrm{s}}^{\mathrm{ad}}$ work of adiabatic compression of air in the compressor/praca adiabatycznego sprężania $w$ sprężarce

$\mathrm{N}_{\mathrm{s}}$ power of the compressor/moc sprężarki

$\mathrm{N}_{\mathrm{t}}$ power of the turbine/moc turbiny

$\mathrm{p}_{1} \quad$ air pressure at the inlet to the compressor/ciśnienie przed sprężarka

$\mathrm{p}_{4} \quad$ exhaust gas pressure at the outlet of the turbine/ciśnienie spalin za turbina

$\mathrm{p}_{2} \quad$ supercharging pressure/ciśnienie doładowania

$\mathrm{p}_{3}$ pressure of exhaust gases before the turbine/ciśnienie spalin przed turbina

$\mathrm{R}$ gas constant of air/stała gazowa powietrza
$\mathrm{R}_{\mathrm{t}}$ gas constant of exhaust gases/stała gazowa spalin

$\mathrm{T}_{1}^{\mathrm{t}}$ air temperature at the inlet to the compressor/temperatura powietrza przed sprężarka

$\mathrm{T}_{2}$ air temperature at the outlet of the compressor/temperatura powietrza za sprężarka

$\mathrm{T}_{3}$ exhaust gas temperature before the turbine/temperatura spalin przed turbina

$\mathrm{W}_{\mathrm{p}}$ coefficient of share of the expenditure of the first sequence compressor/współczynnik udziału wydatku sprężarki pierwszego zakresu

$\mathrm{W}_{\mathrm{t}}$ coefficient of share of the expenditure of the first sequence turbine/współczynnik udziału wydatku turbiny pierwszego zakresu

$\eta_{\mathrm{s}} \quad$ adiabatic efficiency of the compressor/sprawność sprężarki

$\eta_{\text {s.c }}$ total efficiency of the compressor set/calkowita sprawność zespotu sprężarkowego

$\eta_{\mathrm{t}} \quad$ adiabatic efficiency of the turbine/sprawnośc turbiny

$\eta_{\mathrm{t} . \mathrm{c}}$ total efficiency of the turbine set/całkowita sprawność zespotu turbinowego

$\kappa$ exponent of the adiabate of the air/wyktadnik adiabaty powietrza

$\kappa_{\mathrm{t}}$ exponent of the adiabate of the exhaust gases/wyktadnik adiabaty spalin

$\lambda \quad$ air excess coefficient/współczynnik nadmiaru powietrza

$\pi_{\mathrm{s}} \quad$ compressor ratio/spręż sprężarki

$\pi_{\mathrm{t}} \quad$ expansion ratio/stopień rozprężania turbiny

\section{Bibliography/Literatura}

[1] Beineke E., Woschni G.: Rechnerische Untersuchung des Betriebverhaltens ein- und zweistufig aufgeladener mittelschnellaufender Viertaktdieselmotor. MTZ 3/1978.

[2] Bluhm K., Ganz M., Voght R.: Erfahrungen mit der Registeraufladung in einer Reiselimousine. Ref. 11, 3 Aufladetechnische Konferenz, Zürich 14-16.09.1988.

[3] Bode E.: Theoretische Untersuchungen zur zweistufigen Abgasturboaufladung, Dieselmotoren Nachrichten, 2/1969.

[4] Borila Y.G.: A sequential turbocharging method for highlyrated truck diesel engines. SAE Pap. 860074.

[5] Borila Y.G.: Sequential turbocharging helps highly-rated diesels. Automotive Engineering, Nov. 1986.

[6] Borila Y.G.: Same aspects of performance optimization of the sequentially turbocharged highly-rated truck diesel engine with turbochargers of unequal size and a pulse converter. IMechE. Pap. CIOS/1986.

[7] Christmann R., Schmalzl H.-P., Schmitt F., Schwarz A.: Zweistufig geregelte Aufladung für Pkw- und Nfz-Motoren. Motortechnische Zeitschrift MTZ, 1/2005.

[8] Danilecki K.: Trends in the development of turbocharging systems in automotive vehicles. Combustion Engines/Silniki Spalinowe, $\mathrm{nr} 2 / 2008$.

[9] Danilecki K.: Model of turbo-charging system of traction diesel engine. Silniki Spalinowe/Combustion Engines, nr $3 / 2007$.

[10]Delesalle J.: Ein- oder zweistufige Aufladung? Das Verfahren mit reduziertem Verdichtungsverhältnis, Teil 1: Theoretische
Untersuchungen des R.V.R.-Zyklus und der zweistufigen Aufladung. Motortechnische Zeitschrift MTZ, 6/1980.

[11] Esch E.J., Brüstle C., Tran Van K., Wagner J.:Verbesserung des stationären Betriebsverhaltens von abgasturboaufgeladene Ottomotoren. Ref.1. Aachener Koloqium: Fahrzeug und Motorentechnik, Aachen 27-29 Okt. 1987.

[12] Łęgowicz J.: Doładowanie typu twin-turbo. Auto Moto Serwis, $3 / 2005$.

[13] Pflüger F.: Die zweistufig geregelte Aufladung (R2S) - ein neues Aufladesystem für Nfz-Motoren. Motortechnische Zeitschrift MTZ, 7-8/1998.

[14] Steinparzer F., Kratochwill H., Mattes W., Stütz W.: Der neue BMW Sechszylinder-Dieselmotor mit Stufenaufladung . Motortechnische Zeitschrift MTZ, 5/2005.

[15] Wisłocki K.: Systemy doładowania szybkoobrotowych silników spalinowych. WKiŁ, Warszawa 1991.

Mr. Krzysztof Danilecki, DEng. - Doctor at the Chair of Automotive Vehicles Operation, West Pomeranian University of Technology in Szczecin.

Dr inż. Krzysztof Danilecki - adiunkt w Katedrze Eksploatacji Pojazdów Samochodowych Zachodniopomorskiego Uniwersytetu Technologicznego $w$ Szczecinie.

e-mail:kdanilecki@zut.edu.pl 